\title{
ANALISIS KESALAHAN SISWA DALAM MENYELESAIKAN SOAL CERITA BANGUN DATAR SEGIEMPAT DITINJAU DARI KEMAMPUAN PEMECAHAN MASALAH MATEMATIK UNTUK SISWA KELAS VII
}

\author{
Anggraeni Ratna Sari ${ }^{1}$, Usman Aripin ${ }^{2}$ \\ 1,2,3 IKIP Siliwangi Bandung \\ ${ }^{1}$ anggraeniratna.sari@yahoo.com, ${ }^{2}$ usman.aripin@ikipsiliwangi.ac.id, \\ ${ }^{3}$ hendriana@stkipsiliwangi.ac.id
}

\begin{abstract}
This research seeks to explore and reveal students' mathematical problem solving abilities by analyzing student answers. The research subjects were seventh grade students taken from a public junior high school in Purwakarta Regency. The results of the study show that students' mathematical problem solving ability is still very weak and far to be complete even though the level of difficulty of the instrument is in the medium category. In general, the ability of these study subjects in mathematical problem solving is still below $50 \%$. It is time for teachers to apply problem-based learning, in addition to conventional learning models, to provide opportunities and experiences for students to see and experience mathematical problem solving in the classroom. This qualitative study exposes students' responses in dealing with story questions in a rectangular building material. In addition the students are given the questions shown to reveal whether the students are using a systematic solution or can answer directly without a sequence, judging by the ability to solve mathematical problems. There were 6 heterogeneous students who were the subjects in this study. Based on the analysis that has been done, the results obtained are (1) students answer the problem is not systematic, (2) lack of understanding of the sequence of problem solving, (3) students are too hasty in doing math problems.
\end{abstract}

Keywords: Error Analysis, Quadrilateral Build, Problem Solving Ability

\begin{abstract}
Abstrak
Penelitian ini berupaya menggali dan mengungkap kemampuan pemecahan masalah matematis siswa dengan menganalisis jawaban siswa. Subyek penelitian adalah siswa kelas VII yang diambil dari sebuah SMP negeri di Kabupaten Purwakarta. Hasil studi memperlihatkan kemampuan pemecahan masalah matematis siswa masih sangat rendah ini berarti ketuntasan siswa dalam menyelesaikan soal masih sagat kurang meski tingkat kesukaran instrumen berada pada kategori sedang. Sudah waktunya pengajar mengimplementasikan pembelajaran berbasis masalah, daripada menggunakan pembelajaran biasa, sehingga siswa terlatih dalam menyelesaikan suatu permasalahan matematis di kelas. Studi kualitatif ini mengungkap respon siswa dalam menghadapi soal cerita dalam materi bangun datar segiempat. Sebagai tambahan siswa diberikan soal yang ditunjukan untuk mengungkap apakah siswa menggunakan penyelesaian secara sistematis atau bisa menjawab langsung tanpa berurutan, dilihat dari kemampuan pemecahan masalah matematik. Terdapat 6 orang siswa heterogen yang menjadi subjek dalam penelitian ini. Berdasarkan analisis yang telah dilakukan, hasil yang didapatkan adalah (1) siswa menjawab soal tidak sistematis, (2) kurangnya pemahaman urutan pemecahan masalah, (3) siswa terlalu terburu-buru menyelesaikan persoalan yang diberikan.
\end{abstract}

Kata Kunci : Analisis kesalahan, Bangun Datar Segiempat, Kemampuan Pemecahan Masalah

How to cite: Sari, A. R., Aripin, Y. (2018). Analisis Kesalahan Siswa dalam Menyelesaikan Soal Cerita Bangun Datar Segiempat ditinjau dari Kemampuan Pemecahan Masalah Matematik untuk Siswa Kelas VII. JPMI - Jurnal Pembelajaran Matematika Inovatif, 1 (6), $1135-1142$. 


\section{PENDAHULUAN}

Matematika merupakan mata pelajaran penting dalam pendidikan matematika. Matematika juga menjadi induk dalam segala mata pelajarannya. Matematika juga merupakan prasyarat untuk mempelajari berbagai disiplin ilmu, seperti halnya Ruseffendi (2006) menjelaskan mengenai matematika adalah ratunya ilmu (Mathematics is the queen of the sciences), ini dapat diartikan bahwa matematika itu tidak bergantung kepada bidang studi lain.

Materi Bangun Datar untuk kelas 7 sekolah menengah itu menjadi materi dasar untuk materi bangun ruang di kelas 8 , namun siswa sukar dalam memahami dan mengusai materi tersebut. Untuk memenuhi materi bangun datar, bisa ditinjau melalui kemampuan matematika. Diantara kemampuan matematika tersebut yaitu kemampuan siswa dalam memecahkan masalah. Menurut Budiman (Hendriana, Rohaeti, \& Sumarmo, 2017) kemampuan pemecahan masalah memiliki indikator sebagai berikut: a) Mengidentifikasi kecukupan data untuk memecahkan masalah, b) Membuat model matematik dari suatu masalah dan menyelesaikannya, c) Memilih dan menerapkan strategi untuk menyelesaikan masalah matematika, d) Memeriksa kebenaran hasil atau jawaban.

Untuk materi bangun datar, soal-soal yang memuat indikator kemampuan matematik siswa mengenai pemecahan masalah selalu berkaitan dengan lingkungan dan kehidupan sehari-hari siswa. Soedjadi (2000) mengatakan bahwa kemampuan pemecahan masalah adalah suatu keterampilan pada peserta didik agar mampu menggunakan kegiatan matematis untuk memecahkan masalah dalam matematika, masalah dalam ilmu lain, dan dalam masalah kehidupan sehari-hari. Permasalahnnya adalah apa yang diberikan oleh guru kurang sesuai dengan tingkat kemampuan siswa. Guru dibebani dengan bahan ajar yang termuat dalam silabus matematika yang harus dituntaskan tepat pada waktunya, tanpa memperhatikan apakah siswa sudah memahaminya atau belum. Guru menjadikan siswa yang pintar sebagai acuan dalam keberhasilannya menyampaikan konsep, jarang melihat siswa yang lebih lambat mencerna konsep. Ini mengakibatkan sebagian besar siswa kurang menyukai matematika. Padahal diharapkan siswa menyukai matematika sehingga siswa mampu mengaplikasikannya dalam kehidupan sehari-hari. Masalah lainnya adalah kebiasaan siswa menyelesaikan soal matematika bentuk pilihan ganda. Hal tersebut berdampak pada kemampuan siswa berpikir secara skematis. Siswa lebih sering diberikan soal rutin. Saat disajikan soal non-rutin, siswa belum mampu menyelesaikan soal dengan baik. Hal itu berujung pada pekerjaan siswa yang kurang tepat.

Dalam bangun datar sering ditemui soal uraian berbentuk cerita yang membuat siswa kebingungan dan malas membaca soal yang terlihat panjang. Soal uraian berbentuk cerita yang dibuat biasa mengandung kemampuan yang ingin dicapai oleh guru. Dalam postes ini, soal yang disajikan mengandung indikator kemampuan Pemecahan Masalah matematik. Matematika salah satu mata pelajaran penting yang memiliki tujuan umum berdasarkan NCTM yaitu : Komunikasi matematis, Penalaran matematis, pemecahan masalah matematis, koneksi matematis, representasi matematis. Pentingnya kemampuan pemecahan masalah adalah untuk meningkatkan kompetensi pengajar termasuk guru agar lebih baik lagi. Menurut Ruseffendi (2006) mengemukakan bahwa suatu soal merupakan soal pemecahan masalah bagi seseorang bila ia memiliki pengetahuan dan kemampuan untuk menyelesaikannya, tetapi pada saat ia memperoleh soal itu ia belum tahu cara menyelesaikannya.

Menurut Polya (Hendriana, Rohaeti, \& Sumarmo, 2017) mengemukakan bahwa pemecahan masalah adalah suatu usaha mencari jalan keluar dari suatu tujuan yang tidak begitu mudahsegera dapat dicapai. Selain itu Ruseffendi (2006) juga mengemukakan bahwa suatu persoalan itu merupakan masalah bagi seseorang jika: pertama, persoalan itu tidak dikenalnya. 
Kedua, siswa harus mampu menyelesaikannya baik kesiapan mentalnya maupun pengetahuannya siap; terlepas daripada apakah akhirnya ia sampai atau tidak kepada jawabannya. Ketiga, sesuatu itu merupakan pemecahan masalah baginya, bila ia ada niat untuk menyelesaikannya. Penelitian ini bertujan untuk mengkaji kemampuan pemecahan masalah matematik siswa SMP dengan menganalisis jawaban siswa dalam menjawab soal cerita dilihat dari kemampuan pemecahan masalah.

\section{METODE PENELITIAN}

Penelitian ini merupakan penelitian deskriptif dengan menggunakan pendekatan kualitatif. Abdurrahman (Warih, Parta, \& Rahardjo, 2016) mengatakan bahwa penelitian deskriptif bertujuan untuk menggambarkan secara tepat sifat-sifat suatu individu, keadaan, gejala atau kelompok tertentu. Sementara itu Moleong (Warih, Parta, \& Rahardjo, 2016) mengungkapkan bahwa metode penelitian kualitatif sebagai prosedure penelitian yang menghasilkan data deskriptif berupa kata-kata tertulis atau lisan dari orang-orang dan perilaku yang dapat diamati, penelitian ini ditulis untuk menganalisis dan mendeskripsikan kemampuan pemecahan masalah matematis siswa kelas VII dalam materi Bangun datar Segiempat yang berpedoman pada terpenuhi atau tidaknya indikator-indikator pemecahan masalah matematis. Penelitian ini dilaksanakan di SMPN Kabupaten Purwakarta yang berada di Jln. Kopi Ciwareng Kec.Babakancikao Kab.Purwakarta. Subjek dari penelitian ini yaitu 6 orang siswa di SMPN Kabupaten Purwakarta dengan kemapuan heterogen. Peneliti mengambil subjek tersebut berdasarkan dari hasil pertimbangan dari guru, selain itu diharapkan dapat mewakili dari tujuan penelitian.

Teknik pengumpulan data yang dilaksanakan dalam penelitian ini yaitu melakukan kegiatan pendahuluan, menyusun tes kemampuan pemecahan masalah matematis dari soal intrumen, mengkonsultasikan soal tes kemampuan pemecahan masalah matematis dengan pembimbing, mengumpulkan data, menganalisis data dan menarik kesimpulan. Adapun kegiatan pendahuluan yang dilakukan yaitu menentukan lokasi penelitian, meminta ijin dari pihak sekolah, menyampaikan maksud dan tujuan kepada guru mata pelajaran matematika, dan menentukan subyek penelitian. Data yang dikumpulkan berupa hasil tes yang memuat indikator kemampuan pemecahan masalah matematis dari 6 siswa yang sudah ditentukan sebelumnya.

Peneliti merupakan perencanaan, pelaksana pengumpulan data, analis, penafsir data, dan menjadi pelapor hasil penelitiannya. Instrument pendukung pada penelitian ini berupa tes. Tes yang digunakan di penelitian ini yaitu berupa instrumen yang memuat kemampuan pemecahan masalah matematis yang terdiri dari 6 soal berupa soal-soal dengan mengaitkan materi Bangun Datar Segiempat dengan beberapa materi matematika. Pada masing-masing soal siswa harus menyelesaikan permasalahan yang diminta dengan mengaitkan beberapa materi dalam matematika.

Tes yang digunakan telah dikonsultasikan kepada pembimbing. Selain itu, rubik penilaian tes disusun sesuai indikator pemecahan matematis yang telah ditentukan. Pada setiap indikator dijabarkan kemungkinan proses yang dituliskan siswa. Berdasarkan rubik tersebut peneliti bisa memastikan apakah siswa memenuhi masing-masing indikator pemecahan masalah matematik atau tidak. Data yang didapat kemudian disesuaikan dengan rubik penilaian tes. Selanjutnya diolah dengan menentukan presentase keterpenuhan masing-masing indikator pemecahan masalah matematis. Kemampuan pemecahan masalah matematis siswa dikatakan tinggi apabila persentase keterpenuhan indikator pemecahan masalah matematis minimal $75 \%$ 
siswa pada setiap soal. Dilihat juga pengerjaan dalam jawaban siswa apakah secara sistematis atau tidak.

\section{Hasil Penelitian dan Pembahasan \\ Hasil}

Adapun soal nomor 1 ditampilkan sebagai berikut:

1. Sandi memiliki layang-layang, dengan panjang diagonal atas $20 \mathrm{~cm}$, dan diagonal bawah dua kali lebih besar dari diagonal atas, sandi ingin mengetahui luas layang-layang tersebut, menurutmu cukupkah data tersebut untuk menyelesaikan masalah tersebut? Jelaskan jawabanmu sesuai data yang ada.

\section{Gambar 1. Soal Nomor 1}

Dalam soal nomor 1 ini siswa diminta mengidentifikasikan unsur yang diketahui, ditanyakan, dan kecakupan unsur dalam soal Bangun Datar Segiempat tersebut. Berdasarkan hasil analisis, dari 6 siswa yang menjawab soal dengan benar ada 4 orang dengan skor 4,2 siswa sisanya mengalami kesalahan penyelesaian soal. Adapun hasil jawaban siswa sebagai berikut. Untuk gambar.2 adalah jawaban siswa yang benar, namun ada juga siswa yang kurang memahami bagaimana penyelesaian soal tersebut, berikut ini jawaban siswa yang mengalami kesalahan pada penyelesaian soal.

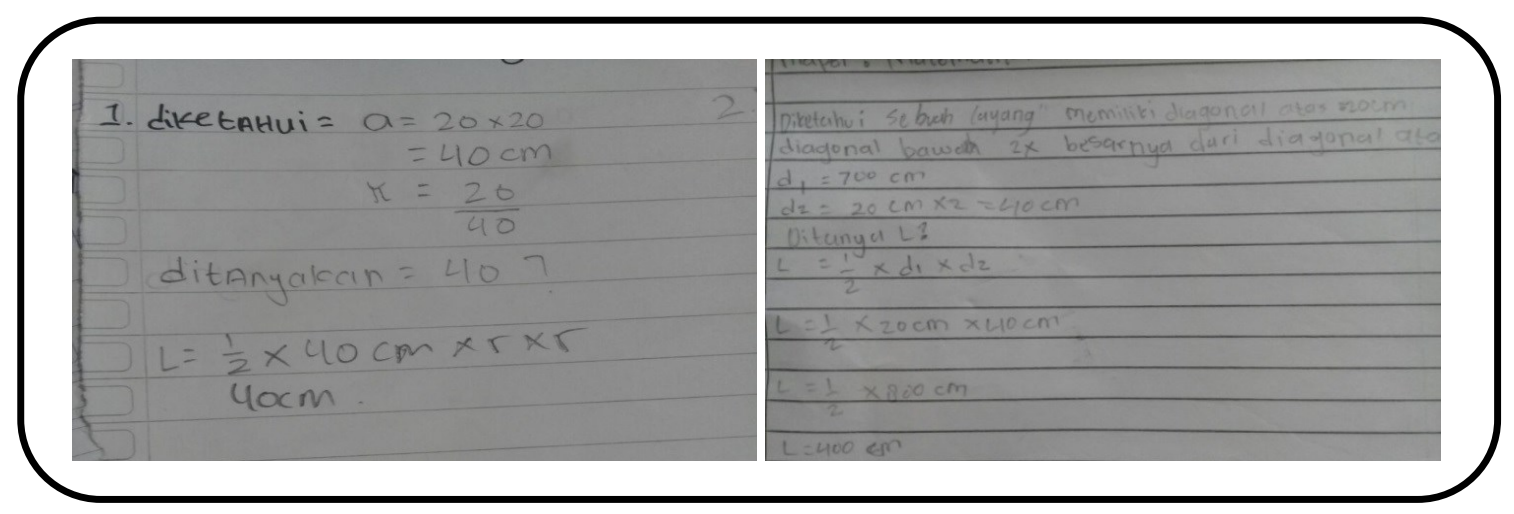

Gambar2. Jawaban Soal Nomor 1

Dalam gambar.3 siswa dalam menjawab terlihat kesalahan saat mengaplikasikan cara penyelesaian dari soal untuk dijawab. Siswa masih kesulitan menentukan apa itu diagonal atas dan diagonal bawah, terlihat saat memasukan rumus luas bangun datar layang -layang.

Adapun untuk soal nomor 2, siswa diharuskan menentukan pemodelan dalam bangun datar segiempat menggunakan aljabar, lalu diaplikasikan dengan mengetahui luas dan keliling bangun datar segiempat.

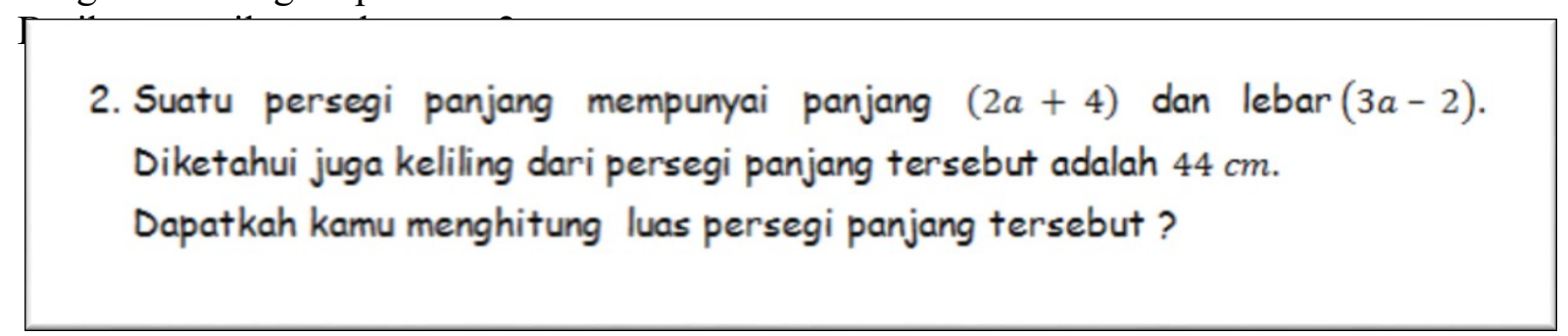

Gambar 3. Soal Nomor 2

Dalam soal nomor 2 siswa diharuskan mencari nilai panjang sebenarnya berapa dan lebarnya berapa agar bisa mencari nilai luas persegi panjang. Berikut jawaban siswa 


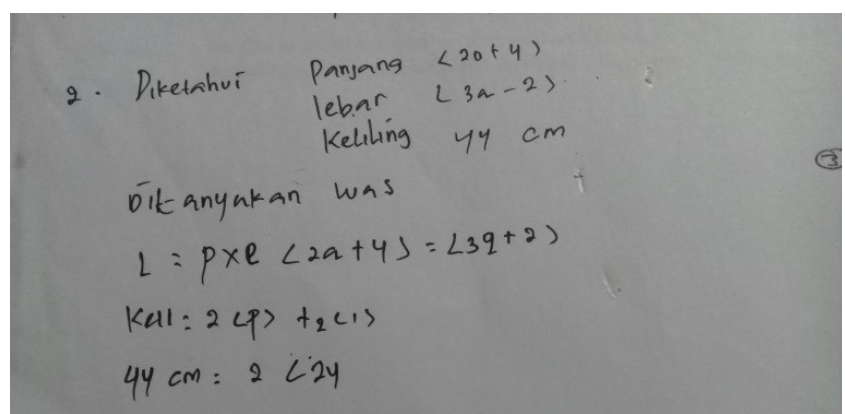

Gambar 4. Jawaban Siswa Nomor 2

Dalam soal nomor dua, 3 siswa menjawab seperti gambar.5 dengan skor 2, artinya siswa kurang memahami soal yang diberikan. Siswa hanya mengingat luas persegi panjang tetapi kurang paham bahwa nilai a harus dicari dahulu dalam menentukan nilai lebar dan panjang persegi panjang. Siswa hanya terpaku dengan data yang ada pada soal juga belum memahami pengaitan sistem aljabar. Berbeda dengan 3 siswa lainnya, mereka sudah mampu menjawab soal sampai mencari nilai panjang dan lebar persegi panjang, namun masih belum lengkap dalam mencapai hasil akhir. Berikut jawaban salah satu siswa tersebut.

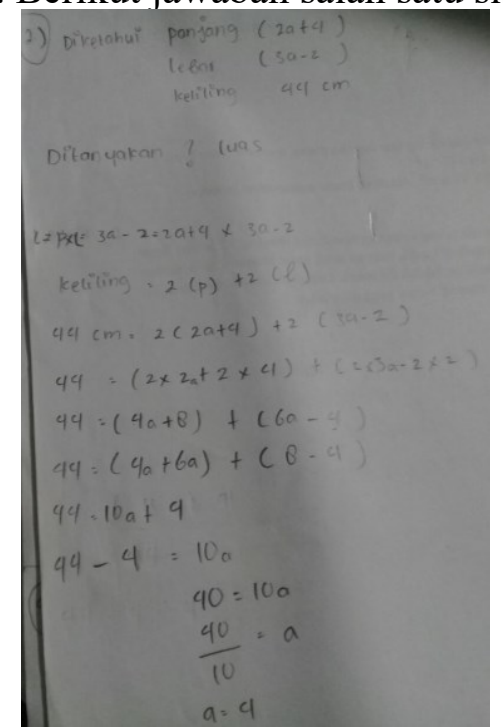

Gambar 5. Jawaban Siswa Nomor 2

Selanjutnya adalah soal nomor 3 , pada soal ini 4 siswa menjawab dengan skor 6 , namun 2 siswa lainnya menjawab dengan skor 4 , berikut jawaban salah satu siswa :

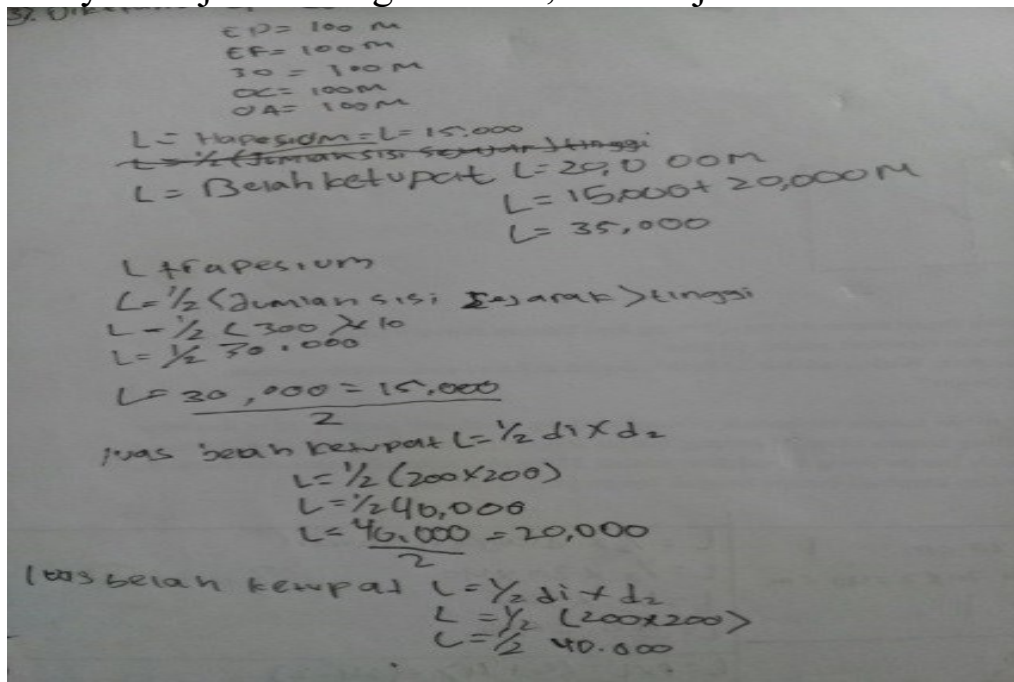

Gambar 6. Jawaban Siswa Soal Nomor 3 
Dalam jawaban siswa tersebut terlihat siswa kebingungan menempatkan rumus mana dan bangundatar segiempat yang terlebih dahulu dihitung, siswa juga kurang mengindetifikasi soal yang membuat siswa kurang memahami soal dan menjawab soal dengan tidak teliti. Dalam mencari pemecahan masalah siswa harus memahami dan mengidentifikasikan persoalan yang disajikan agar memudahkan siswa menjawab soal yang diberikan. Dalam menerapkan rumus pun siswa masih kebingungan. Pada jawaban tersebut, siswa mendapat skor 4, karena dalam menuliskan rumus belum lengkap dan dalam operasionalnya tidak selesai, meskipun jawabannya benar

Selanjutnya soal nomor 4, hanya 2 dari 6 siswa yang menajwab benar dengan skor 8,4 siswa lainnya menjawab kurang lengkap dengan skor 3. Berikut jawaban siswa belum lengkap:

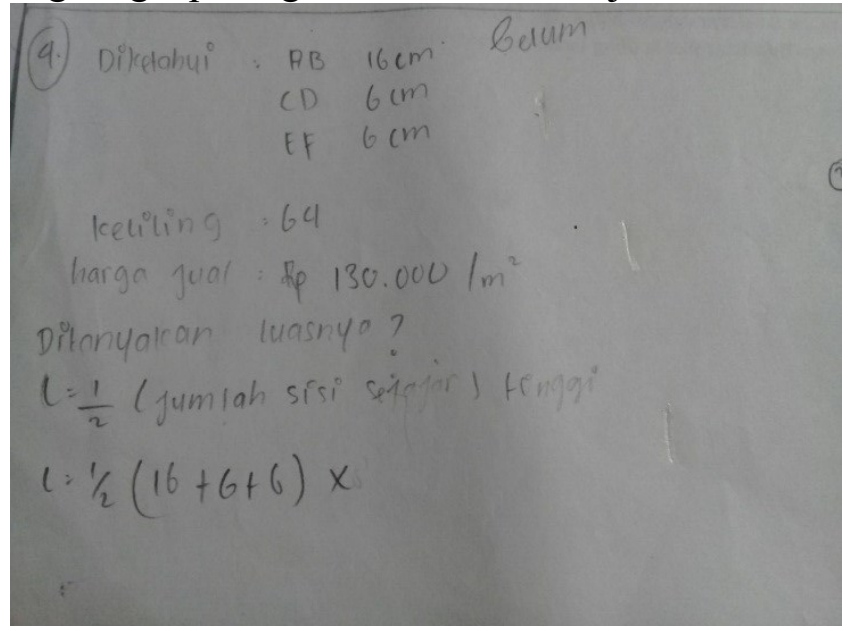

Gambar 7. Jawaban Siswa Soal Nomor 4

Untuk jawaban siswa tersebut, siswa memahami rumus yang harus digunakan namun siswa masih kebingungan menentukan cara mencari tinggi dalam bangun datar trapesium, dan siswa masih belum dapat mengaplikasikan yang diketahui kedalam rumus

Selanjutnya untuk soal nomor 5, dari 6 siswa hanya 3 siswa yang mengisi soal nomor 5, itupun jawabannya belum selesai, berikut jawaban siswa

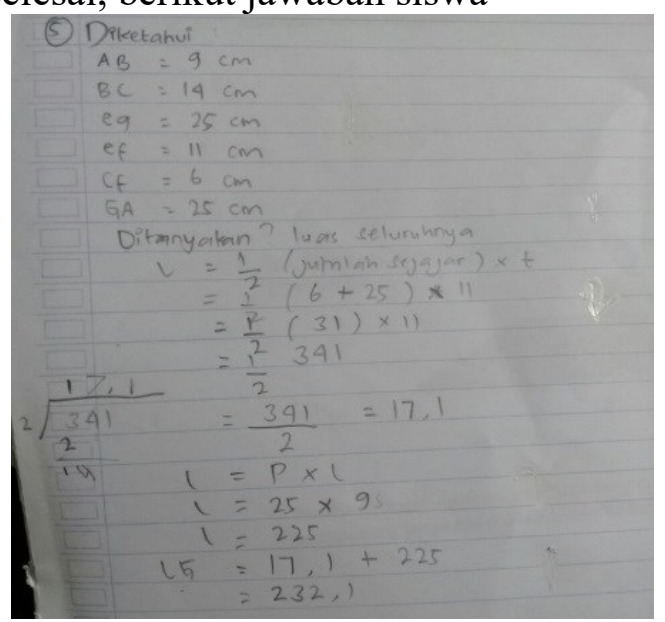

Gambar 8. Jawaban Siswa Nomor 5

Dalam jawaban tersebut, siswa telah mengidentifikasi soal yang memudahkan siswa menjawab soal, namun saat pengoperasian dan pengaplikasian rumus dengan data yag diketahui siswa masih kebingungan , siswa mengoperasikan data yang ada namun tidak dipahami mana yang harus digunakan dalam menghitung dengan rumus yang ada. Selanjutnya untuk soal nomor 6 , dari 6 siswa tidak ada yang menjawab, dikarenakan waktu yang tidak mencukupi. 


\section{Pembahasan}

Menurut siswa permasalahan yang disajikan termasuk sulit, karena siswa masih banyak yang kebingungan pada saat menyelesaikan permasalahan dan mengidentifikasi soal tersebut siswa pun mengakui terlalu tergesa-gesa dalam menyelesaiakan soal akan materi Bangun datar segimpat tersebut. Berdasarkan indikator pemecahan masalah jawaban siswa belum mencapai maksimal, terlihat dari jawaban hasil tes yang diberikan, dan siswa juga banyak yang kesulitan pada saat menyelesaikan soal tersebut. Hal ini ditunjukan dengan hasil tes awal kemampuan pemecahan masalah matematis siswa tidak melakukan pengkoneksian secara maksimal. Siswa masih belum bisa mengaplikasikan konsep yang telah dipelajari sebelumnya dengan konsep yang ada di Bangun datar segiempat sehingga kesulitan dalam menyelesaikan soal. Kesulitan yang dialami siswa yakni pada saat memahami soal karena siswa masih bingung dan belum mampu mengidentifikasikan unsur cerita yang ada dalam soal. Selain itu siswa juga lupa dengan materi dan konsep bangun datar segiempat. Selain itu, siswa masih bingung menentukan strategi yang akan dipakai untuk menyelesaikan soal. Siswa juga dalam pengerjaan kurang paham dalam mengoperasikan rumus yang telah diketahui. Begitu pula dalam menjawab soal, jawaban siswa masih belum runtut sesuai tahapan pemecahan masalah. Menurut Branca (Purnomo \& Mawarsari, 2016) bahwa kemampuan pemecahan masalah adalah tujuan utama dalam pembelajaran matematika, oleh karena itu kemampuan pemecahan masalah hendaknya diberikan, dilatihkan dan dibiasakan kepada peserta didik sedini mungkin sehingga guru harus dapat memberikan cara pemecahan masalah semudah dan semenarik mungkin agar siswa memahami masalah dan yang diberikan dan mampu menemukan pemecahan yang terbaik dari setiap permasalahan. Dengan demikian mahasiswa sebagai calon tenaga pengajar dan pendidik matematika khususnya harus dibekali dengan kemampuan pemecahan masalah secara baik sehingga saat mereka terjun dilapangan tidak mengalami kesulitan yang berarti.

Menurut Novtiar \& Aripin (2017) matematika juga mengajarkan pola berpikir kritis, analitis dan sistematis dalam pemecahan masalah baik pada pelajaran matematika atau dalam kehidupannya. Dalam hal ini, meskipun siswa belum memperoleh jawaban yang tepat, tetapi siswa telah berusaha untuk mengaitkan konsep-konsep yang lalu dengan konsep baru yang terdapat pada Bangun datar segiempat. Hasil penelitian awal ini difokuskan memberikan informasi tambahan kepada peneliti untuk mengkaji mengenai kemampuan pemecahan masalah matematis siswa mengingat pentingnya pemecahan masalah matematis serta fakta mengenai kemampuan pemecahan masalah matematis siswa, diharapkan guru mampu merancang kegiatan belajar mengajar yang dapat menunjang kemajuan kemampuan pemecahan masalah matematis siswa.

\section{KESIMPULAN}

Berdasarkan hasil analisis dan pembahasan, disimpulkan bahwa kemampuan pemecahan masalah matematik siswa kelas VII SMPN Kabupaten Purwakarta saat memecahkan soal Bangun datar segiempat harus ditingkatkan lagi, saat memecahkan persoalan yang disajikan siswa kurang memahami cara menjawab dengan sitematis dan menggunakan sistem pemecahan masalah. Penelitian ini diharapkan agar pengajar lebih menambahkan pendekatan dan metode pembelajaran agar lebih membuat siswa bersemangat dan termotivasi dalam belajar, dan bertambah pemahamannya mengenai materi bangun datar segiempat.

\section{UCAPAN TERIMA KASIH}

Ucapan terimakasih disampaikan untuk semua yang membantu, membimbing dan mengarahkan sampai penelitian ini berjalan dengan baik hingga selesai. Untuk Kepala 
Sekolah SMP Babakancikao, Guru Pamong Matematika, bapak dosen pembimbing dan siswa siswi kelas 7A SMPN 1 Babakancikao.

\section{DAFTAR PUSTAKA}

Hendriana, H., Rohaeti, E. E., \& Sumarmo, U. (2017). HARD SKILLS dan SOFT SKILLS MATEMATIK SISWA. (N. F. Atif, Ed.). Bandung: PT Refika Aditama.

Novtiar, C., \& Aripin, U. (2017). DAN KEPERCAYAAN DIRI SISWA SMP MELALUI, $V I(2), 119-131$.

Purnomo, E. A., \& Mawarsari, V. D. (2016). Peningkatan Kemampuan Pemecahan Masalah Melalui Model Pembelajaran Ideal Problem Solving Berbasis Project Base Learning, 1 .

Ruseffendi, E. T. (2006). Pengantar Kepada membantu Guru Mengembangkan Kompetensinya dalam Pengajaran Matematika Untuk Meningkatkan CBSA. Bandung: Tarsito.

Soedjadi, R. (2000). Kiat Pendidikan Matematika di Indonesia. Direktorat Jenderal Pendidkan Tinggi Departemen Pendidkan Nasioanal.

Warih, P. D., Parta, I. N., \& Rahardjo, S. (2016). Analisis kemampuan koneksi matematis siswa kelas VIII pada materi teorema Pythagoras. Prosiding Konferensi Nasional Penelitian Matematika dan Pembelajarannya [KNIP I], (Knpmp I), 377-384. Diambil dari http:/hdl.handle.net/11617/6978 